Anton Panda; Kostiantyn Dyadyura; Jozef Mihok; Iveta Pandová; Daniela Onofrejová

\title{
MODELLING OF THE STRUCTURE AND THE REQUIRED LEVEL OF PERFORMANCE PROPERTIES OF A POLYTETRAFLUOROETHYLENE COMPOSITES FOR SEALING
}

\author{
Anton Panda \\ Technical university in Košice, Faculty of manufacturing technologies with the seat in \\ Prešov, Štúrova 31, 08001 Prešov, Slovakia, anton.panda@ tuke.sk (corresponding author) \\ Kostiantyn Dyadyura \\ Sumy State University, Faculty of Technical Systems and Energy Efficient Technologies, Rimsky-Korsakov 2, 40007 \\ Sumy, Ukraine, dyadyura@pmtkm.sumdu.edu.ua \\ Jozef Mihok \\ Technical University of Kosice, Faculty of Mechanical Engineering, Department of Industrial Engineering and \\ Management, Nemcovej 32, 04200 Kosice, jozef.mihok@ tuke.sk \\ Iveta Pandová \\ Technical university in Košice, Faculty of manufacturing technologies with the seat in \\ Prešov, Štúrova 31, 08001 Prešov, Slovakia, iveta.pandova@ tuke.sk \\ Daniela Onofrejová \\ Technical University of Kosice, Faculty of Mechanical Engineering, Department of Industrial Engineering and \\ Management, Nemcovej 32, 04200 Kosice, daniela.onofrejova@tuke.sk
}

Keywords: simulation, polytetrafluoroethylene, sealing, tensile strength

Abstract: The article describes the mathematical modelling results of the dynamics in order to determine the regularity. Further development of numerical approaches to taking into account the geometric nonlinearity of composite material on the basis of polytetrafluoroethylene with the use of the finite element method for studying the stress-strain state of the sealing elements line. Simulation were carried out under combined axial and surface radial loads. It is determined that the most "dangerous" from the point of view of the strength of the design are areas around square openings, docking zones of spherical, conical and cylindrical parts.

\section{Introduction}

One of the trends in the development of modern technology is the increasing use of composite materials in its production. This allows the material to be reduced in design without losing the required strength and stiffness characteristics. Promising in this regard are polymer composite materials (PCM) based on polytetrafluoroethylene (PTFE) due to its unique operational properties - the lowest coefficient of friction among polymers, high chemical inertia, thermal and cold resistance $[1,2]$. In the process of designing structures on the basis of fibrous composites, a preliminary calculation of deformation, strength and other structural characteristics is made. Analysis of these calculations in the future makes it possible to correct structural features by changing the mechanical properties of the composite and design parameters (size, shape, etc.).

A number of constructs of modified PCM based on PTFE, in particular by mechanical activation and/or the introduction of appropriate functional fillers, in geometric nonlinear relationships between stresses and deformations are have shown in real conditions of operation. The specified nature of deformation requires the development of conceptually new ways of its consideration [3-7]. There is a need for the development of methods for solving such problems in three-dimensional formulation, in particular the finite element method [2-4,8,9].

The aim of this work is to solve the problem of determining the stress-strain state of spatial structures of composite sealants based on the improvement of elastic constancy models and the development of effective numerical approaches to the solution of boundary-value problems of the mechanics of a deformable solid.

\section{Materials and Methods \\ 2.1 Materials}

The main objective of the work is to develop antifriction composite material with high physical and mechanical properties for use in heavy wear. The main criteria laid down in the development of such materials is the ability to work without lubrication, reduced wear and tear of the part itself and the combined surface, resistance to the chemical impact of aggressive media, reliable work at low temperatures. As a polymer matrix that best satisfy the above criteria selected PTFE (Figure 1) because of its 
MODELLING OF THE STRUCTURE AND THE REQUIRED LEVEL OF PERFORMANCE PROPERTIES OF A POLYTETRAFLUOROETHYLENE COMPOSITES FOR SEALING

Anton Panda; Kostiantyn Dyadyura; Jozef Mihok; Iveta Pandová; Daniela Onofrejová

unique properties. The choice of fillers for the study is justified by the following considerations.

The results of research in the field of PCM based on PTFE convincingly proved the effectiveness of the use of carbon fiber (Figure 2). Established its optimal content of PTFE composites varies over a wide range (5-20) wt. \% depending on the grade of the filler $[3,6,10,11]$. The prospects of modifying the surface of carbon fibers by mechanical activation [3,5,10,12]. Consequently, carbon fiber is selected as the main fibrous filler for a series of experiments.

Surface layer carbon fiber is characterized by microniveness with the sizes which do not exceed $(0,1-0,2)$ microns, formed during carbonization and graphitization of hydrate cellulose tissue (Figure 2).

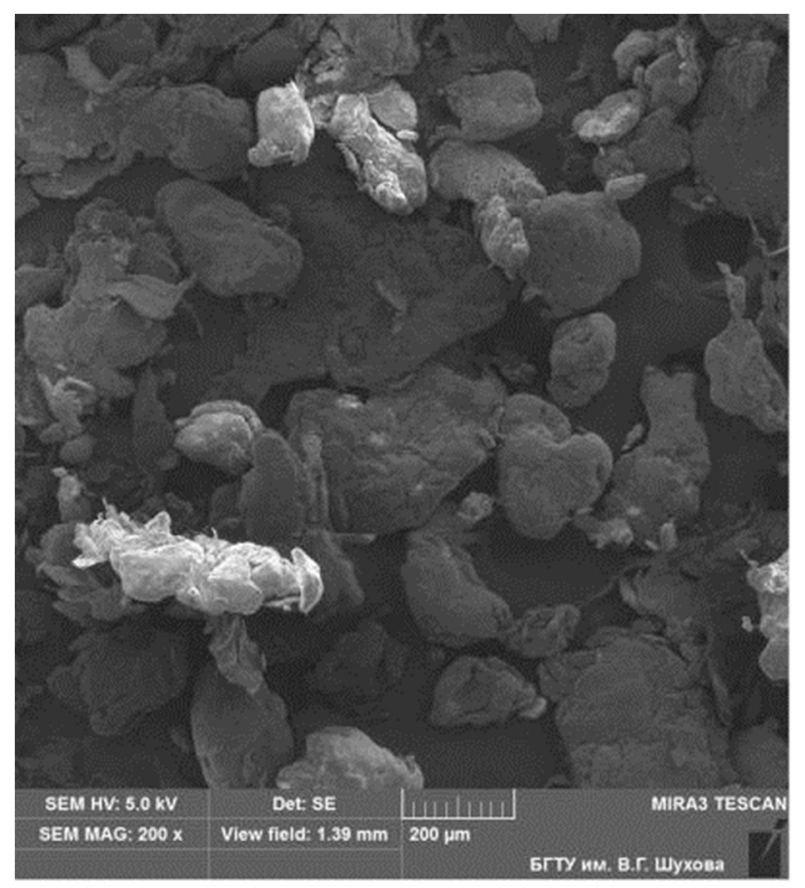

Figure 1 Microstructure of industrial PTFE

The presence of such superficial defects of different structures and geometric sizes allows us to use technological techniques based on the processes of deformation of the boundary layers on the surface of the filler as a result of their filling with particles of PTFE [14].

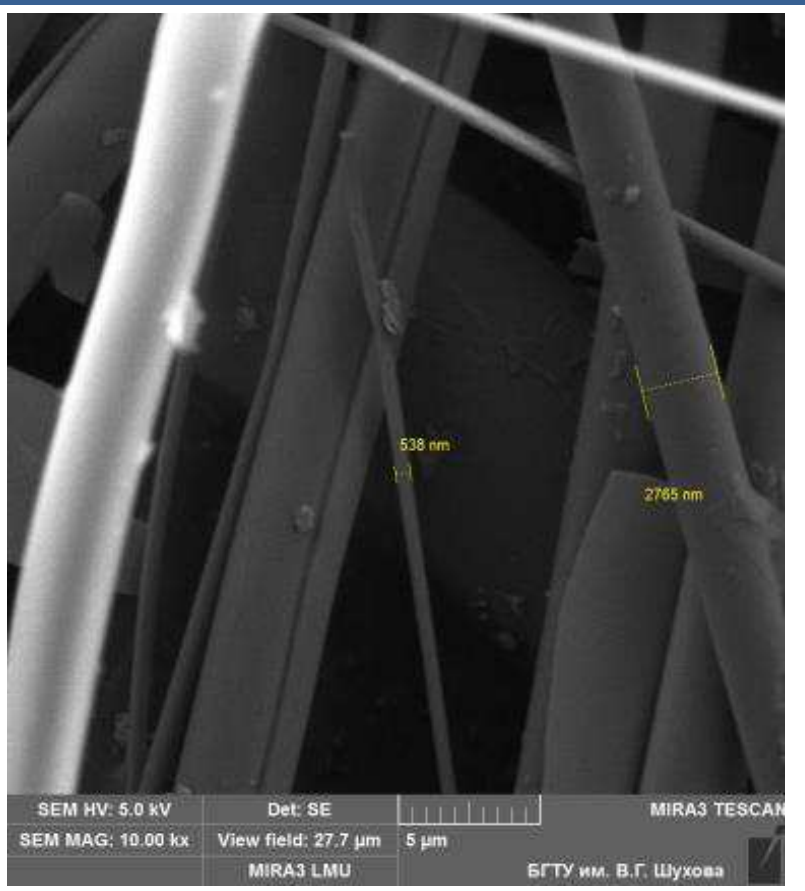

Figure 2 Microstructure of the surface of the fragment carbon fiber $(x 7480)$

On the basis of experiments, it was found out that PTFE used for these studies is the most relevant for the requested requirements (Table 1).

\begin{tabular}{|c|c|}
\hline Characteristic & $\begin{array}{c}\text { Value of the } \\
\text { index for the } \\
\text { material }\end{array}$ \\
\hline \multicolumn{2}{|l|}{ Mechanical Properties } \\
\hline Density, g/cc & $2,13-2,19$ \\
\hline $\begin{array}{l}\text { Tensile strength (Moulding } \\
\text { direction), } \mathrm{MPa} \\
\text { Elongation at break } \\
\text { (Moulding Direction), \% }\end{array}$ & $\begin{array}{c}15-35 \\
150-350\end{array}$ \\
\hline Hardness (Shore D) & $57-64$ \\
\hline $\begin{array}{l}\text { Deformation under load, \% } \\
1 \mathrm{hr}, 23^{\circ} \mathrm{C}, 14.2 \mathrm{MPa} \\
24 \mathrm{hrs}, 23^{\circ} \mathrm{C}, 14.2 \mathrm{MPa} \\
\text { permanent deformation } \\
1 \mathrm{hr}, 150^{\circ} \mathrm{C}, 5 \mathrm{MPa}\end{array}$ & $\begin{array}{c}11,8 \\
14,3 \\
7,9 \\
10,0\end{array}$ \\
\hline $\begin{array}{l}\text { Compressive modulus at } \\
0.2 \% \text { off-set, } 23^{\circ} \mathrm{C}, \mathrm{MPa}\end{array}$ & $600-700$ \\
\hline $\begin{array}{l}\text { Flexural modulus at } 0.2 \% \\
\text { off-set, } 23^{\circ} \mathrm{C}, \mathrm{MPa}\end{array}$ & 690 \\
\hline
\end{tabular}

High molecular weight carbon fibers are widely sought after in the production of composite materials due to the unique combination of physical, mechanical and chemical 
MODELLING OF THE STRUCTURE AND THE REQUIRED LEVEL OF PERFORMANCE PROPERTIES OF A POLYTETRAFLUOROETHYLENE COMPOSITES FOR SEALING

Anton Panda; Kostiantyn Dyadyura; Jozef Mihok; Iveta Pandová; Daniela Onofrejová

properties (Table 2) such as high modulus of elasticity and strength, low density, high electrical conductivity, low coefficient of friction and thermal expansion, high resistance to atmospheric influences and chemical reagents [12].

Table 2 Main characteristics of carbon-fibers [13,14]

\begin{tabular}{|c|c|}
\hline Parameter & Value \\
\hline Carbon content, \% & $80,0-99,5$ \\
\hline Diameter $\mathrm{d} \cdot 10^{-6}, \mathrm{~m}$ & $4-30$ \\
\hline Density, $\mathrm{kg} / \mathrm{M}^{3}$ & $1400-2000$ \\
\hline Longitudinal strength, $\mathrm{Pa}$ & $0,1-3,5$ \\
\hline Tensile modulus, $\mathrm{hPa}$ & $10-7000$ \\
\hline Tensile elongation & $0,5-1,3$ \\
\hline $\begin{array}{l}\text { Specific thermal capacity } \\
\lambda \cdot 10^{3}, \mathrm{~J} /(\mathrm{kg} \cdot \mathrm{K})\end{array}$ & $0,8-1,7$ \\
\hline Conductivity factor, $\mathrm{W} /(\mathrm{m} \cdot \mathrm{K})$ & $0,8-125,6$ \\
\hline Electrical resistivity, Ohm·m & $1 \cdot 10^{-5}-1 \cdot 10^{4}$ \\
\hline${ }_{1}^{\text {Thermal expansivity } \alpha \cdot 10^{6}, \mathrm{~K}^{-}}$ & $2-20$ \\
\hline BET surface area, $\mathrm{m}^{2} / \mathrm{g}$ & $0,3-1000,0$ \\
\hline Burning duration, $\mathrm{s}$ & $3-300$ \\
\hline $\begin{array}{l}\text { Resistance } \mathrm{K} \text { to oxygen under } \\
\text { an inert or reducing } \\
\text { atmosphere }\end{array}$ & $\begin{array}{l}\text { to } 673-723 \text {, } \\
\quad \text { to } 3273\end{array}$ \\
\hline
\end{tabular}

\subsection{Mathematical simulation and optimization of composite structures based on polytetrafluoroethylene for ensuring high wear- resistance properties}

Consider the two-phase composite material of random structure, which consists of a polymer continuous matrix, reinforced by the random distribution of discrete inclusions in it. The choice of two-phase material as a research object somewhat simplifies (in comparison with the threecomponent composite) mathematical calculations and, at the same time, contains all the hypotheses and the initial preconditions for further research. In addition, this approach allows us to consider some well-studied twocomponent structures - materials with spherical inclusions and materials, reinforced with short fibers. In Figure 3 shows the structure of two-component material, inclusions in which there are short fibers.

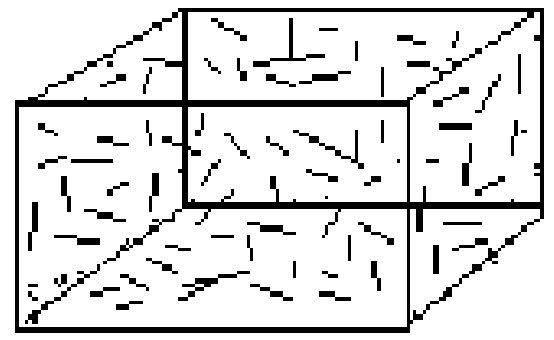

Figure 3 Structure of the two-component material based on polytetrafluoroethylene reinforced with carbon fibers

The elastic spring element creates a constant force that pushes the sealing edges for sealing along the mating surfaces of the groove.

When modelling the stress-strain state of a rubber ring, finite elements were used for which the Mooney-Rivlin model (1) was implemented [13,15]:

$$
\begin{aligned}
& \quad W=C_{10} \cdot\left(I_{1}^{*}-3\right)+C_{01} \cdot\left(I_{2}^{*}-3\right)+ \\
& +\frac{1}{D_{1}} \cdot k\left(I_{e}^{*}-1\right)^{2}
\end{aligned}
$$

where: $\mathrm{C}_{10}, \mathrm{C}_{01}$ and $\mathrm{D}_{1}$ are material constants, $I_{1}^{*}, I_{2}^{*}, I_{e}^{*}$ are reduced strain invariants.

Constants of material can be used to calculate the initial shear modulus (2) as follows:

$$
\mu_{0}=2 \cdot\left(C_{10}+C_{01}\right)
$$

The initial modulus of elasticity for a material is calculated (3), (4) as follows:

$$
\begin{gathered}
K_{0}=\frac{1}{D_{1}} \\
\text { Use for analysis } \\
D_{1}=\frac{1}{500 \cdot G}
\end{gathered}
$$

where: $G$ is shear modulus.

To take into account the stress relaxation of the sealing element made of elastomer in the model (1), the Mooney Rivlin constants were recalculated based on the value of the relative residual strain of 0.6 ; the following values were obtained [11,15-21]: $\mathrm{C}_{10}=781178.6 \mathrm{~Pa} ; \mathrm{C}_{01}=154173.9$ $\mathrm{Pa}$.

Deformations of PTFE protective rings were considered elastic, the surfaces of the cylinders and the floating piston were determined to be absolutely rigid. Used friction model [9]:

$$
\tau=\mu \cdot N
$$

where: $\tau$ is the shear stress; $\mu$ is friction coefficient; $N$ is contact normal pressure.

The seal consists of a polymer shell, which is tightened by a metal spring after installation in the seat groove (Figure 4). 


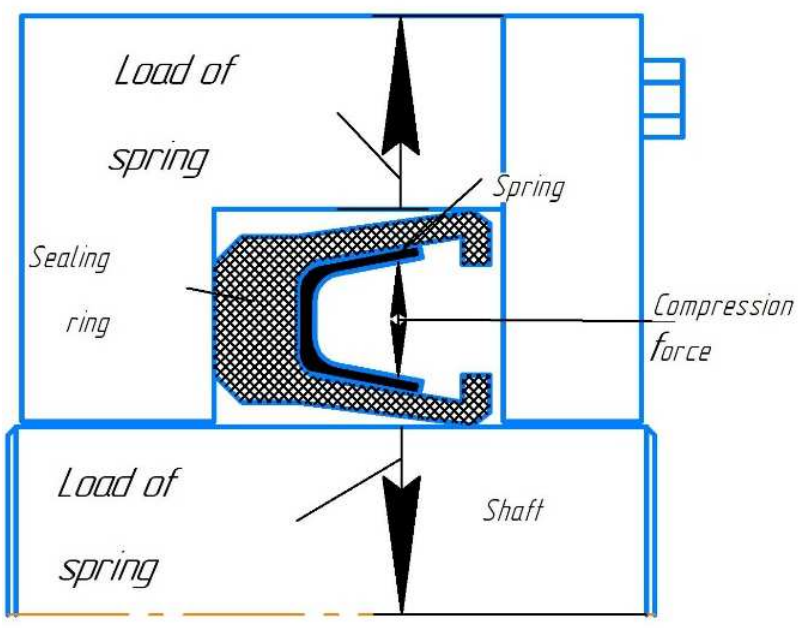

Figure 4 The principle of operation of the sealing

One of the basic calculations for designing seals is the static strength calculation. To determine the stress-strain state of the elements, apply the momentary scheme of the finite element [12].

\section{The results of the simulation performance} properties of a polytetrafluoroethylene composites for sealing

Conducted simulation in the software package SimulationXpress Study.

The following data were taken as input parameters for the simulation model:

- a geometric model of the sealing device (Figure 5);

- characteristics of physical and mechanical properties of materials;

- pressure (20 MPa).

The design of the sealing ring by finite elements can be presented in the next three months by the following intermediary processes:

- preparation of initial data - description of the topology of the design, kinematic and force boundary conditions, physical and mechanical characteristics of the composite material, finite-element sampling of the design and others;

- numerical calculation of finite element model calculation of coefficients of the matrix of rigidity of finite elements, formation of a global system of solving equations and its solution;

- processing of the solution results - calculation of the parameters of the stress-strain state of the design; their visual representation in the form of tables, charts, twodimensional or three-dimensional images.

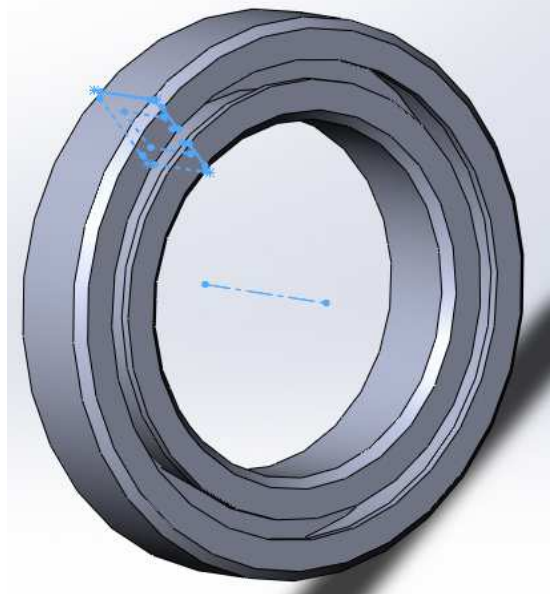

a)

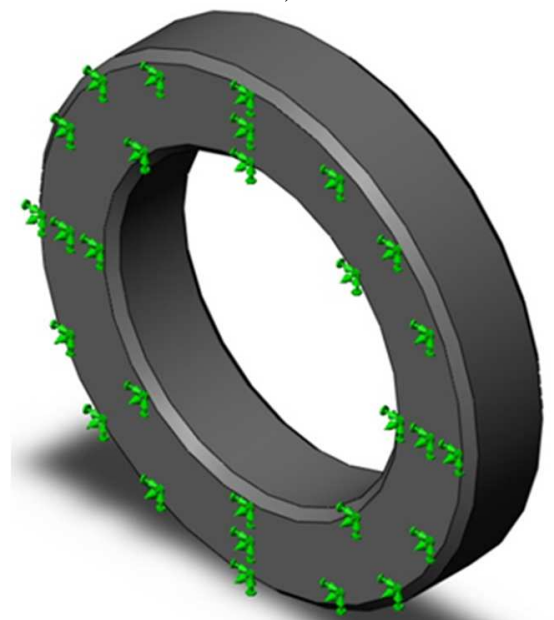

b)

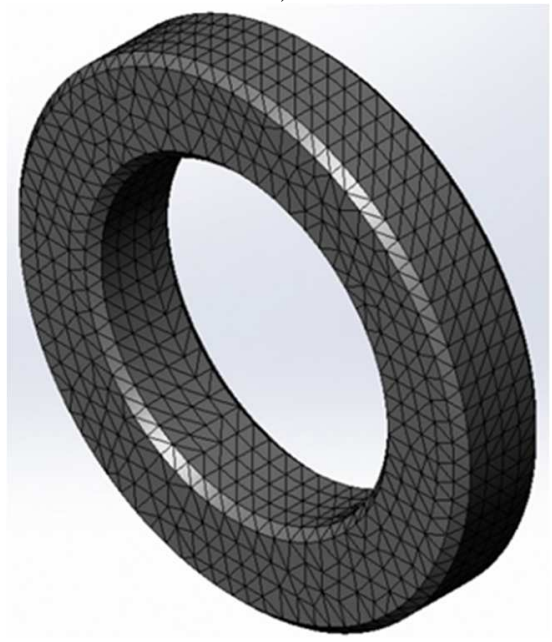

c)

Figure 5 The research in SimulationXpress Study Stress

a) 3D CAD model;

b) Fixed geometry;

c) Finite elements 
MODELLING OF THE STRUCTURE AND THE REQUIRED LEVEL OF PERFORMANCE PROPERTIES OF A POLYTETRAFLUOROETHYLENE COMPOSITES FOR SEALING

Anton Panda; Kostiantyn Dyadyura; Jozef Mihok; Iveta Pandová; Daniela Onofrejová

For the study of the stress-strain state of structures of fibrous composites, the ratios for the stiffness matrix of a three-dimensional finite element of composite material with transistor components are proposed, taking into account the spatial reinforcement of fibers based on the momentum scheme of a finite element. The momentary scheme avoids the disadvantages inherent in the traditional scheme of the finite element, and the consideration of the spatial nature of the location of the fibers weakens the requirements for the discretization of structures.

The obtained diagrams of equivalent voltages for the sealing element of the device under consideration are shown in Figure 6. As can be seen from Figure 6, in the sealing element in a static state, the maximum equivalent voltage is $2199 \mathrm{~Pa}$, which cannot lead to the destruction of the sealing element. After relaxation of the stresses in the power element, the equivalent stresses in the sealing ring decrease, as well as the decrease of the contact pressure on the sealing surface.

The diagram of equivalent stresses, shown in Fig. 4, corresponds to the development of adhesive bonds at the point of contact during a long stop of the mechanism. According to the literature data, the initial (starting) value of the friction coefficient can reach values of 0.2 and more [17]. At high values of the friction coefficient, the equivalent stresses locally increase, which exceeds the tensile strength for the applied group of polymers. The initial friction at the time of launch, as well as high values of the friction force in the process of movement or rotation of the shaft can lead not only to damage the surface of the sealing ring, but also to its twisting.

The nature of the external load and the symmetry violation, due to the presence of openings in the structure, leads to the fact that radial displacement has both a positive and a negative sign, that is, there are zones that are torn, and there are zones that bend. Although these displacements are in an order of magnitude smaller than the axial.

The values of the axial displacements in the intersections perpendicular to the axis of the design are close to the steady ones, although they are not such that due to the presence of rectangular openings and, accordingly, asymmetrical setting of the problem. The analysis of the results shows that the most vulnerable in terms of strength are areas near rectangular openings, where the intensity values of the stresses acquire the maximum values.

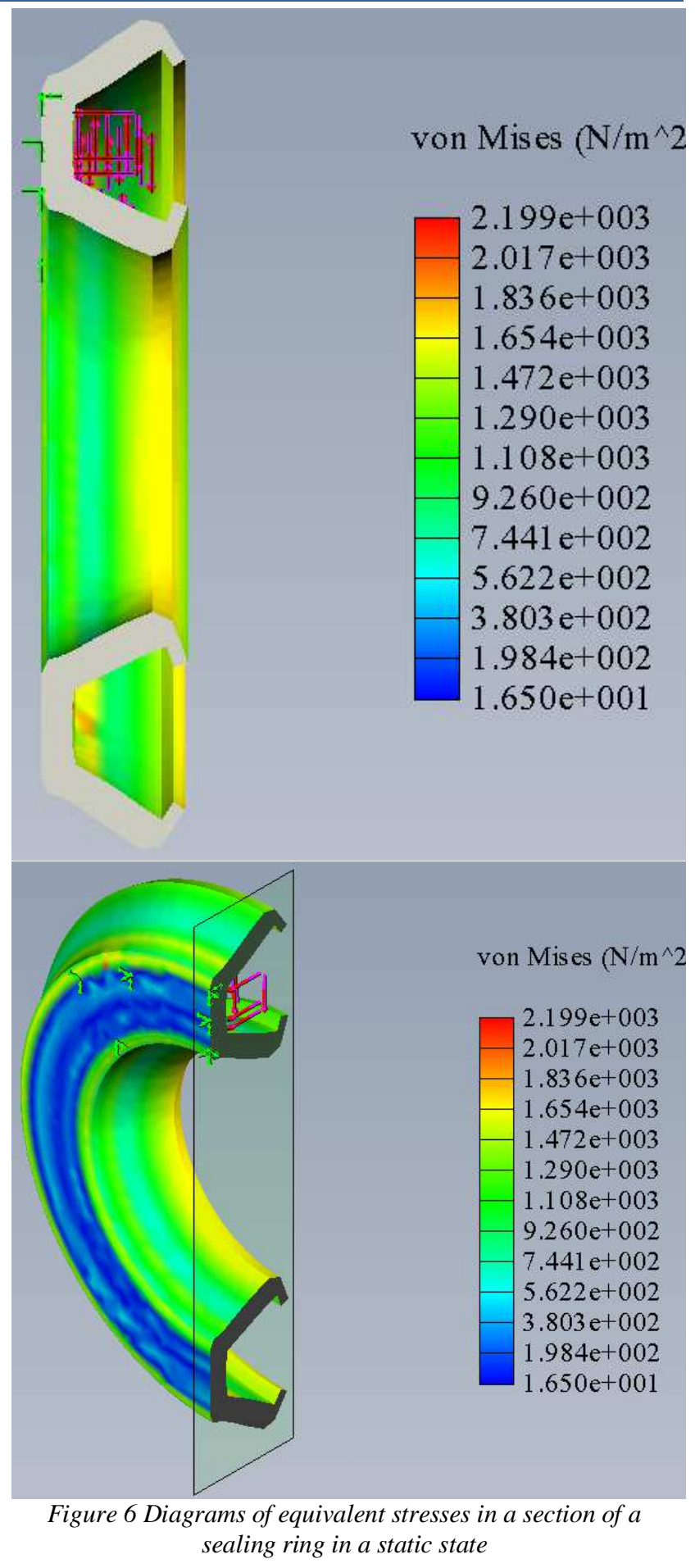

\section{Conclusions}

On the basis of established factors of mechanical activation, content and properties of fillers, the performance characteristics were obtained by antifriction material based on PTFE with increased physical and mechanical properties for use in conditions of intense wear. The developed polymer composite materials are 
MODELLING OF THE STRUCTURE AND THE REQUIRED LEVEL OF PERFORMANCE PROPERTIES OF A POLYTETRAFLUOROETHYLENE COMPOSITES FOR SEALING

Anton Panda; Kostiantyn Dyadyura; Jozef Mihok; Iveta Pandová; Daniela Onofrejová

characterized by high wear resistance and relatively low for the PTFE composites tensile modulus values (up to 197 $\mathrm{MPa})$, which increase the area of actual contact of the sealing element made of PTFE-nanocomposite and sealing surface in the sealing device. This combination of properties makes it possible to recommend the developed PTFE nanocomposites for the manufacture of sealing elements of sealing devices for movable joints of machines and technological equipment.

With the help of developed approaches to determination of effective elastic stable composite, matrix of rigidity of a finite element and software complex, the stress-strain state of sealing structures is determined. On the basis of the kinematic and energy conditions of the agreement, analytical relations are proposed for determining the effective elastic characteristics of the fibrous composite material, which allow taking into account the transposition properties of the matrix and fiber. Simulation were carried out under combined axial and surface radial loads. Improving the efficiency of PCM in sealing devices is ensured by a rational choice of the geometrical parameters of the elements of sealing devices, providing the level and distribution of contact pressure on the sealing surface necessary for improving their reliability (durability) at acceptable values of wear and mechanical stresses in the sealing element.

The obtained ratios for the determination of effective characteristics of polymer composites and the developed software complex can be applied at designing and improving the designs of sealing. The maximum values of the compressive stresses at different reinforcement schemes take higher values for the case of the internal arrangement of the composite layer in comparison with the continuous arrangement (up to $30 \%$ ).

Thus, the goal set in the work was achieved and the stated research objectives were solved.

\section{Acknowledgement}

The authors would like to thank the KEGA grant agency for supporting research work the project KEGA: 004TUKE-4/2017 "Implementation of research from mathematical modelling of microgeometry surface relation on consequential qualitatively parameters part produced with cutting machining into subjects of new study programme Technology of automotive production".

This article was created by implementation of the grant project APVV-17-0258 "Digital engineering elements application in innovation and optimization of production flows".

\section{References}

[1] VAIL, J.R., KRICK, B.A., MARCHMAN, K.R., SAWYER, W.G.: Polytetrafluoroethylene (PTFE) fiber reinforced polyetheretherketone (PEEK) composites, Wear, Vol. 270, No. 11-12, pp. 737-741, 2011. doi:10.1016/j.wear.2010.12.003
[2] VAS, L.M., PÖLÖSKEI, K., FELHÕS, D., DEÁK, T., CZIGÁNY, T.: Theoretical and experimental study of the effect of fiber heads on the mechanical properties of non-continuous basalt fiber reinforced composites, Express Polymer Letters, Vol. 1, No. 2, pp. 109-121, 2007.

doi:10.3144/expresspolymlett.2007.19

[3] BIJWE, J., SHARMA, M.: Nano and micro PTFE for surface lubrication of carbon fabric rein forced polyethersulphone composites, Tribology of Nanocomposites (Materials Forming, Machining and Tribology), Heidelberg: Springer, 2, pp. 19-39, 2013. doi:10.1007/978-3-642-33882-3_2

[4] D.W. SMITH Jr. SCOTT, T.I., SURESH, S.I.: Handbook of fluoropolymer science and technology, Wiley,Hoboken, 2014. doi:10.1002/9781118850220.

[5] JIN, FAN-LONG, PARK, SOO-JIN: Preparation and characterization of carbon fiber-reinforced thermosetting composites: a review, Carbon letters, Vol. 16, No. 2, pp. 67-77, 2015. doi:10.5714/CL.2015.16.2.067

[6] VENKATESWARLU, G., SHARADA, R., BHAGVANTH, RAO, M.: Polytetrafluoroethylene (PTFE) based composites, Journal of Chemical and Pharmaceutical Research, Vol. 6, No. 10, pp. 508517, 2014.

[7] MASUELLI, M.A.: Introduction of fibre-reinforced polymers-polymers and composites: concepts, properties and processes, Masuelli, M. (ed.) Fiber Reinforced Polymers - The Technology Applied for Concrete Repair, pp. 3-40, 2013. doi:10.5772/54629

[8] PLINTA, D., KRAJČOVIČ, M.: Production System Designing with the Use of Digital Factory and Augmented Reality Technologies, Advances in Intelligent Systems and Computing, Vol. 350, pp. 187-196, 2016.

[9] KHEDKAR, J., NEGULESCU, I., MELETIS, E.: Sliding wear behavior of PTFE composites, Wear, Vol. 252, No. 5-6, pp. 361-369, 2002. doi:10.1016/S0043-1648(01)00859-6

[10] BISWAS, S.K., VIJAYAN K.: Friction and wear of PTFE - a review, Wear, Vol. 158, No. 1-2, pp. 193211, 1992. doi:10.1016/0043-1648(92)90039-B

[11] DULINA, L., EDL, M., FUSKO, M., RAKYTA, M, SULIROVA, I.: Digitization in the Technical Service Management System, MM Science Journal, No. 1, pp. 2260-2266, 2018.

[12] BUZNIK, V.M., VOPILOV, YU.E., IVANOV, V. K., SIGACHEV, A.S., POLYAKOV, V.S., SMIRNOV, M.A., KULAGINA, T.P., SOROKIN, YU.V., TARASOV, V.P., KHARITONOVA, E.P., YURKOV G.YU.: Structure of polytetrafluoroethylene powders obtained by photochemical polymerization of gaseous monomer, Inorganic Materials: Applied Research, Vol. 4, 
MODELLING OF THE STRUCTURE AND THE REQUIRED LEVEL OF PERFORMANCE PROPERTIES OF A POLYTETRAFLUOROETHYLENE COMPOSITES FOR SEALING

Anton Panda; Kostiantyn Dyadyura; Jozef Mihok; Iveta Pandová; Daniela Onofrejová

No. 2, pp. 131-137. 2013
doi:10.1134/S2075113313020044

[13] STRAKA, M., TREBUNA, P., ROSOVA, A., MALINDZAKOVA, M., MAKYSOVA, H.: Simulation of the process for production of plastics films as a way to increase the competitiveness of the company, Przemysl Chemiczny, Vol. 95, No. 1, pp. 37-41, 2016.

[14] BUDNIK, A.F.: Physical and chemical aspects of mechanical activation of polytetrafluoroethylene composite in obtaining and recycling, EasternEuropean Journal of Enterprise Technologies, Vol. 2, No. 11(68), pp. 9-15, 2014 doi:10.15587/1729-4061.2014.23381

[15] DYADYURA, K., BERLADIR, K., RUDENKO, P., BUDNIK, O.A., SVIDERSKIJ, V.A.: Research of Properties of Composite Material Based on Polytetrafluoroethylene Filled with Carbon Fiber with Titanium Nanocoating, Nanomaterials: Applications \& Properties (NAP-2016): $6^{\text {th }}$ International Conference, Lviv, 14-19 September, 2016. - Sumy: Sumy State University, 2016. - V. 5, No $2 .-2016$. doi:10.1109/NAP.2016.7757305.

[16] HUDÁK, R., VARGA, R., HUDÁK, J., PRASLIČKA, D., POLÁČEK, I., KLEIN, P., EL KAMMOUNI, R., VAZQUEZ, M.: Influence of Fixation on Magnetic Properties of Glass-Coated Magnetic Microwires for Biomedical Applications,
IEEE Transactions on Magnetics, Vol. 51, No. 1, pp. 1-4, 2015.

[17] MOLAZEMHOSSEINI, A., TOURANI, H., NAIMIJAMAL, M.R., KHAVANDI, A.: Nanoindentation and nanoscratching responses of PEEK based hybrid composites reinforced with short carbon fibers and nano-silica, Polymer Testing, Vol. 32, No. 3, pp. 525534, 2013. doi:10.1016/j.polymertesting.2013.02.001

[18] BUDNIK, A.F.: Preparation polytetrafluoroethylene powder by method of mechanical activation, Patent 101976, Ukraine, MPK (2006.01): C08J5/04, publ. 12.10.2015, bull. No 19/2015.

[19] BUDNIK, O.A., BUDNIK, A.F. BERLADIR, K.V. RUDENKO, P.V., SVIDERSKIY, V.A.: Influence of mechanical activation polytetrafluoroethylene matrix of tribotechnical composites at its structural and phase transformations and properties. Functional Materials, Vol. 22, No. 4, pp. 499-506, 2015. doi:10.15407/fm22.04.499

[20] BERLADIR, K.V.: Nanostructural modification of polytetrafluoroethylene and its composition by energy influence, Journal of Nano-Electronic Physics, Vol. 8, No. 1, pp. 01033-1 - 01033-5, 2016.

[21] RUIZ, P., MACANÁS, J., MUÑOZ, M., MURAVIEV, D.: Intermatrix synthesis: easy technique permitting preparation of polymerstabilized nanoparticles with desired composition and structure, Nanoscale Research Letters, 6, pp. 343, 2011. doi:10.1186/1556-276X-6-343 